\title{
Article \\ Study, Development and Prototyping of a Novel Mild Hybrid Power Train for a City Car: Design of the Turbocharger
}

\author{
Roberto Capata ${ }^{1, *(1)}$ and Enrico Sciubba ${ }^{2}$ \\ 1 Department of Mechanical \& Aerospace Engineering, University of Roma "Sapienza", 00184 Rome, Italy \\ 2 Department of Industrial Engineering, University “Niccolò Cusano", 00166 Rome, Italy; \\ enrico.sciubba@gmail.com \\ * Correspondence: roberto.capata@uniroma1.it; Tel.: +39-06-445-85243
}

\section{check for}

updates

Citation: Capata, R.; Sciubba, E. Study, Development and Prototyping of a Novel Mild Hybrid Power Train for a City Car: Design of the Turbocharger. Appl. Sci. 2021, 11, 234. https://doi.org/10.3390/app11010234

Received: 18 October 2020

Accepted: 22 December 2020

Published: 29 December 2020

Publisher's Note: MDPI stays neutral with regard to jurisdictional claims in published maps and institutional affiliations.

Copyright: () 2020 by the authors. Licensee MDPI, Basel, Switzerland. This article is an open access article distributed under the terms and conditions of the Creative Commons Attribution (CC BY) license (https: / / creativecommons.org/ licenses/by/4.0/).

\begin{abstract}
Within a large, state-funded, Italian National Project aimed to test the feasibility of an on-the-road prototype of a mild hybrid city vehicle, one of the tasks was to conceive, design and implement an innovative turbocharger that would allow for some energy recovery. The selected vehicle is propelled by a 3-cylinder, $998 \mathrm{cc}$ turbocharged engine (the $66 \mathrm{~kW}$ Mitsubishi-Smart W451). The idea is to implement two types of energy recovery: one via the new turbocharger and one through a standard braking energy recovery (also known as KERS). The study of the former is the object of this paper. The proposed turbocharger configuration consists of mechanically separated, electrically coupled compressor and turbine, possibly mounting only slightly modified commercial equipment to reduce construction costs. This paper reports the results of the calculation of the behavior of the new turbocharging group across the entire engine operating range and describes the preliminary design of the unit. An accurate simulation of a mixed (urban and extra-urban) driving mission demonstrates that a net saving of about $5.6 \%$ can be attained by the installation of the novel turbocharger unit.
\end{abstract}

Keywords: turbocharger; mild hybrid propulsion; vehicle energy balance

\section{Introduction}

Issues related to the road transportation system and the proposed solutions are currently being debated worldwide. The crux of this debate is whether to shift to electric vehicles (EVs) because of their purported "zero emission capability" and high conversion efficiency, or to devise novel configurations for the gasoline (or diesel or LPG or methane) fueled engines. On the wave of strong subsidies to an "electric transition", this field is attracting public and private investors, and the market, although still a niche one, is booming: worldwide sales of plug-in cars increased by about $8 \%$ in 2018-2019. There are three main types of electric vehicles: battery powered (battery electric or BEVs), ICE-hybrid (HEVs) and fuel cell powered (FCVS) [1-3]. Compared to traditional ICE, the propulsion system is fully or partially powered by batteries or smaller ICE or fuel cells, and the traction can be all-electric or mixed (the ICE and the electric motor power separate axles). Advanced electronic equipment is used to monitor and control battery packs, electric motors, power converters, sensors, energy flow management, etc. and has become a key element in the design and implementation of this type of vehicle. The subject of this research is the study and implementation of an innovative supercharger for the ICE (998 cc) of a city car, the Mitsubishi-Smart W451. The design concept is to mechanically disconnect the compressor/turbine unit, powering the compressor with a dedicated electric motor and extracting extra work via a turbine-driven generator. Such a decoupling, currently implemented only on Formula cars and also developed at prototype stage by the Garret corporation [4], allows for both machines to be designed so that they operate very close to their respective maximum efficiency within the expected real operating ranges (dictated by the engine map). Specifically, the turbine is expected to have a lower rotation rate than the original group and will, therefore, be slightly larger. The advantage is that in current supercharged 
groups the surplus at lower and higher regimes is discharged through the waste-gate valve without expanding in the turbine. In the configuration proposed here, instead, all of the energy of the exhaust gases is exploited by the turbine to generate electrical power that can be channeled into the battery pack. Such a configuration is called a mild hybrid vehicle (MHV).

\section{Compressor Re-Design}

Since the vehicle displacement and power $(998 \mathrm{CC})$ are assigned, the natural choice is to use (and possibly slightly reconfigure) the compressor currently installed, i.e., the Garrett GT12 model, whose operational map is shown in Figure 1. In view of the modifications implemented on the compressor geometry and briefly described below, it is useful to summarize here the conceptual design procedure [5-9]:

1. The nameplate volumetric flow rate $\dot{Q}_{\text {nom }}=\dot{m} / \rho_{\text {nom }}$ is calculated at the rotor intake, at standard $p_{0}$ and $T_{0}$ conditions $(298 \mathrm{~K}, 1 \mathrm{bar})$;

2. The design compression ratio $\beta$ is imposed, and the polytropic specific work is calculated by:

$$
W=c_{p, a v} T_{0}\left(\beta^{\frac{k-1}{k \cdot \eta p}}-1\right)
$$

3. Using the design peripheral speed of the current industrial version of the machine, $U_{\text {des }}$, the required head coefficient is obtained:

$$
\psi_{2}=\frac{W_{E U L}}{\eta_{m} U_{d e s}^{2}}
$$

4. If the obtained $\psi_{2}$ value is acceptable (i.e., falls within the range of values historically adopted in similar machines with technically satisfactory results), only one stage will be sufficient. This is the case for the present situation.

The next step is to perform a preliminary design of the stage, i.e., to define all of its dimensions and shape ratios, choosing the materials and proceeding to a final design [10-12]. In our case, it was decided to modify the compressor design adopting a tandem configuration (Figure 2) consisting of an axial inducer followed by a radial exducer, maintaining the same inlet and outlet section diameters as in the Garrett GT12. The details of the necessary modifications and the DOE-CFD-aided configuration optimization are reported in detail in [13], and only the final results will be presented here. The modified compressor has a higher compression ratio than the original unit with an improved surge margin and a lower sensitivity to choking: its characteristic is shown in Figure 3, together with the corresponding engine operating points. The results of the preliminary design of the compressor are displayed in Table 1. 


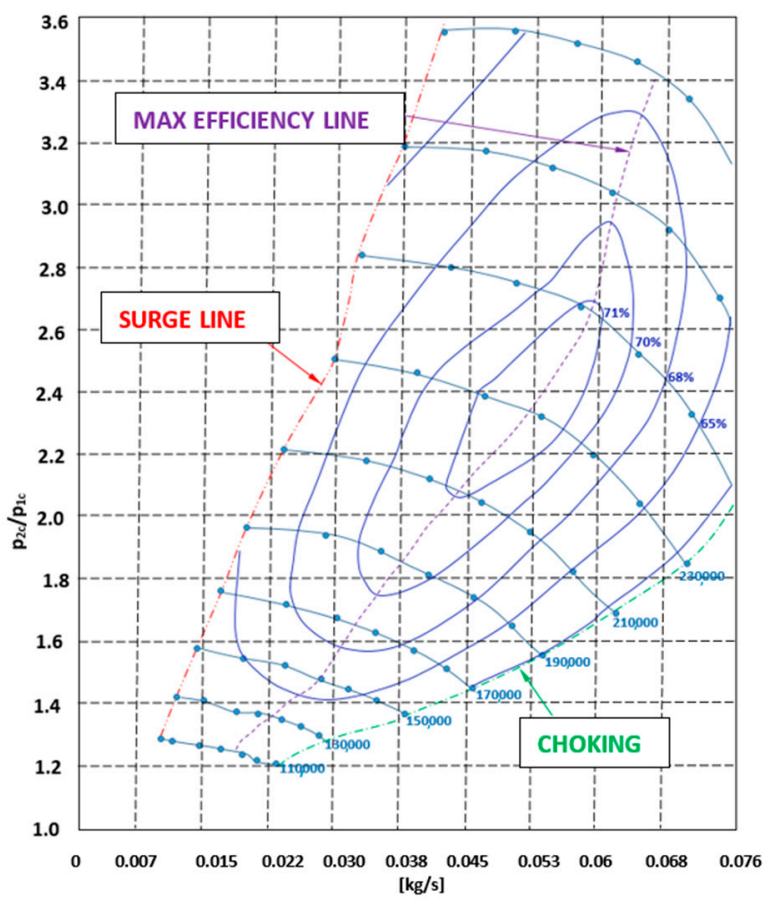

Figure 1. Garrett GT12 Compressor operative map and operating points; on x-axis the corrected mass flow, on y-axis the pressure ratio.

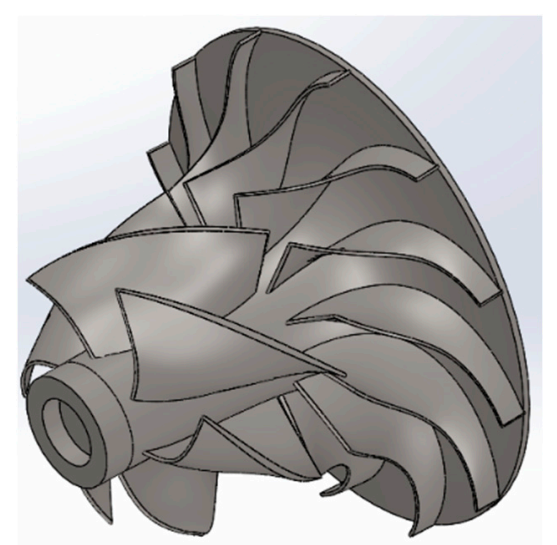

Figure 2. CAD (Computer Aided Design) rendering of the new tandem compressor.

Table 1. Tandem version of the GT12 compressor operating points (new design).

\begin{tabular}{cccccccc}
\hline ICE rpm & $\dot{\boldsymbol{m}}[\mathbf{k g} / \mathbf{s}]$ & Compressor rpm & $\boldsymbol{\beta}_{\mathbf{c}}$ & $\mathbf{T}_{\text {in }}[\mathbf{K}]$ & $\mathbf{T}_{\text {out }}[\mathbf{K}]$ & $\mathbf{P}[\mathbf{W}]$ & $\boldsymbol{\eta}$ \\
\hline 2000 & 0.021 & 145,000 & 1.42 & 298.4 & 344 & 920.71 & 0.68 \\
3500 & 0.0408 & 180,000 & 1.64 & 297.5 & 354 & 2474.39 & 0.8 \\
5500 & 0.0619 & 210,000 & 1.78 & 297.5 & 366.8 & 4444.96 & 0.82 \\
\hline
\end{tabular}



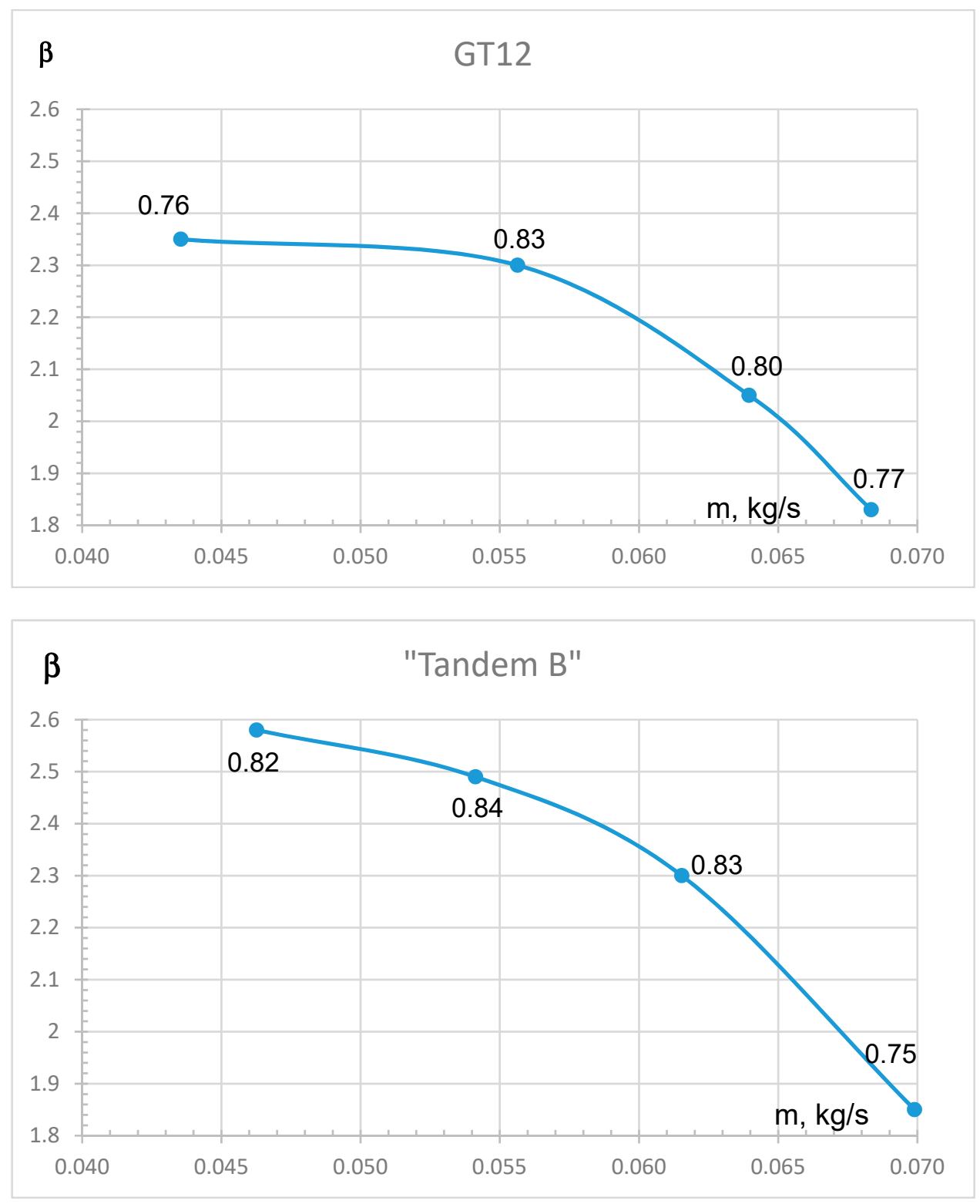

Figure 3. Comparison between the operating lines of the original GT12 compressor and of the redesigned "optimal" configuration ("Tandem B", adapted from [13]). Both curves are labelled by the TC efficiency.

\section{Preliminary Re-Design of the Turbine}

In an electrically coupled turbocharger it is not possible to use the original GT12 component, because its design points depend on the operation of the waste-gate valve, and as such it would not be able to properly respond to the engine conditions nor to supply the required extra power [14-18]. The selection and redesign of the turbine are detailed in a separate work [19], and only a brief summary is repeated here. The selected turbine is a modified Garrett GT20 (operative map in Figure 4), with an accurate redesign of the blade shapes to improve its efficiency and delay choking. In particular, the rotor blade number was increased (14 vs. the original 9), the rotor profile shape and fluid/blade angles were modified, and an 11-blade variable-angle one replaced the original fixed nozzle. The final design and the characteristic curve are shown in Figure 5, and the operating points are displayed in Table 2. 


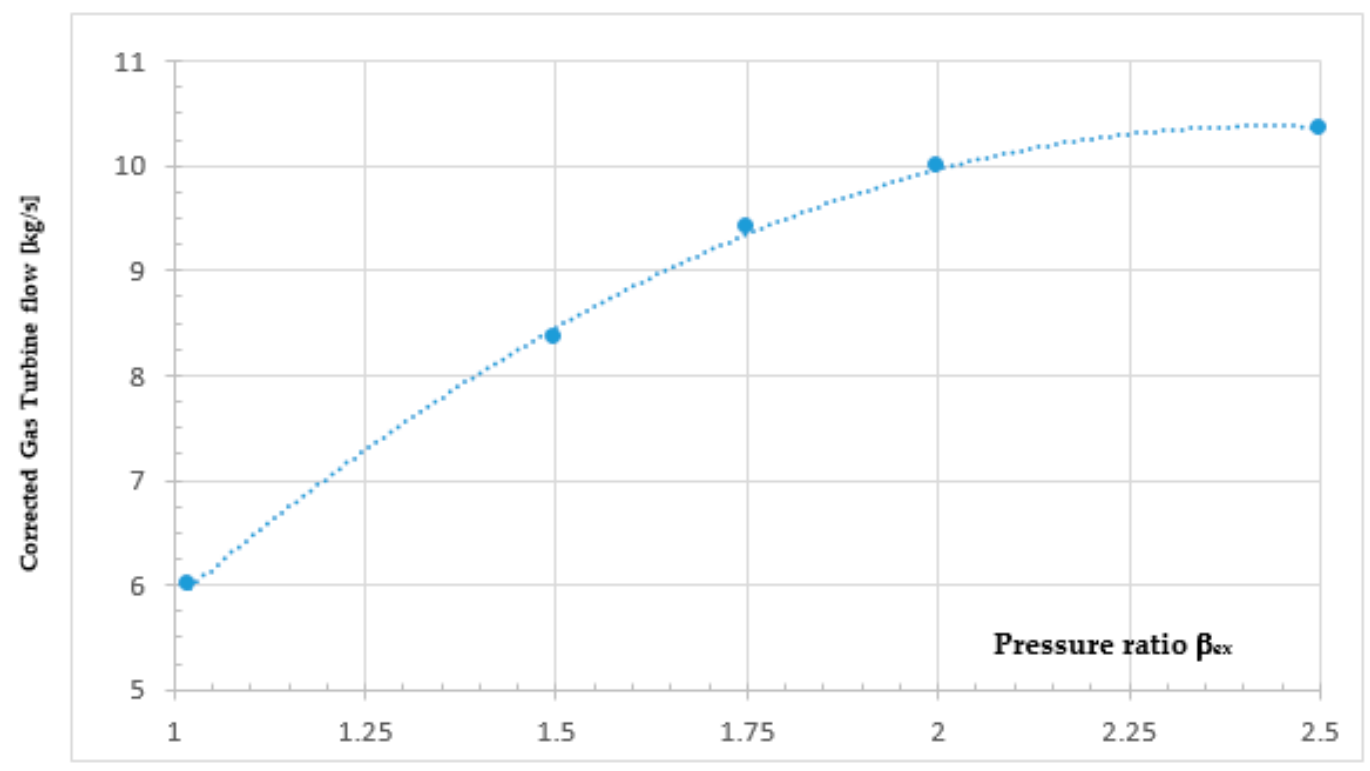

Figure 4. GT20 operative map.
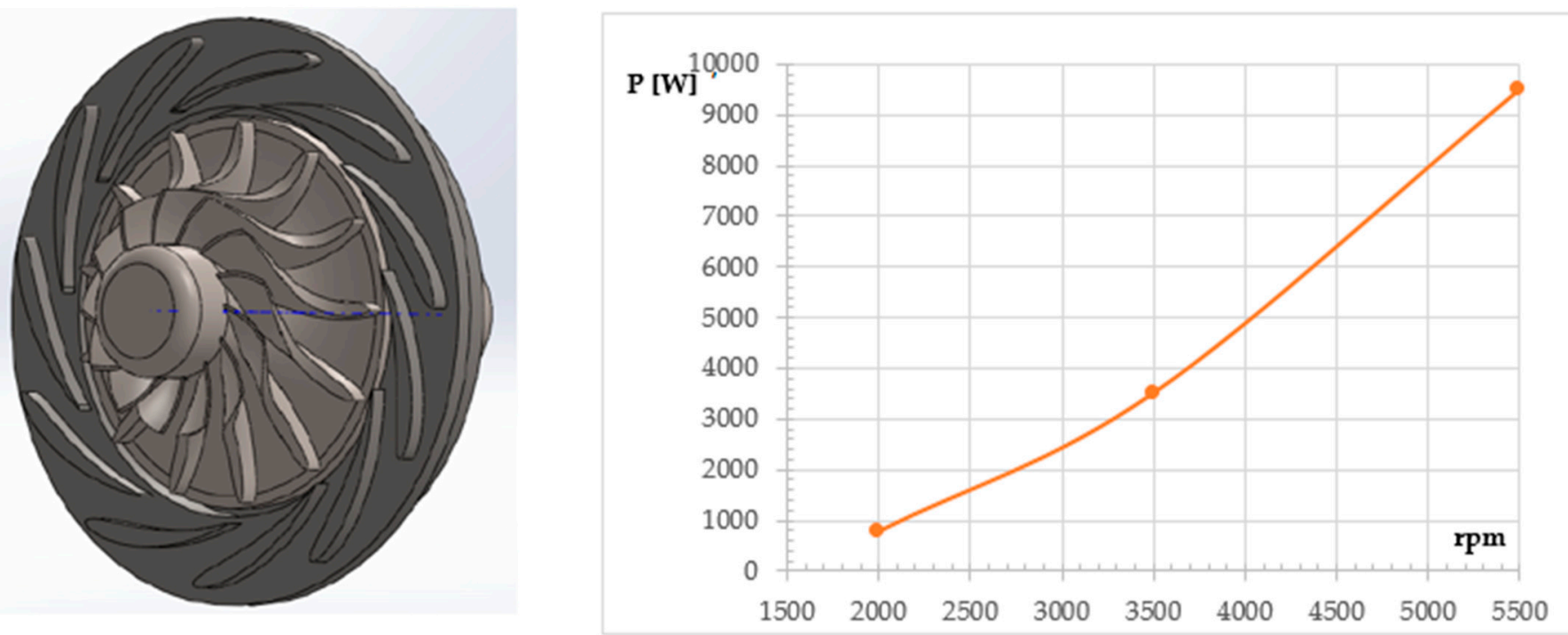

Figure 5. CAD rendering of the proposed design for the turbine and new GT20 operative points.

Table 2. The modified GT20 turbine operating points.

\begin{tabular}{cccccccc}
\hline ICE rpm & $\dot{\boldsymbol{m}}[\mathbf{k g} / \mathbf{s}]$ & Turbine rpm & $\boldsymbol{\beta}_{\mathbf{c}}$ & $\mathbf{T}_{\text {in }}[\mathrm{K}]$ & $\mathbf{T}_{\text {out }}[\mathrm{K}]$ & $\mathbf{P}[\mathbf{W}]$ & $\boldsymbol{\eta}$ \\
\hline 2000 & 0.024 & 82,170 & 1.2 & 954 & 922 & 780 & 0.87 \\
3500 & 0.04 & 134,483 & 1.6 & 1005 & 930 & 3510 & 0.86 \\
5500 & 0.07 & 164,002 & 2 & 1045 & 932 & 9500 & 0.81 \\
\hline
\end{tabular}

\section{Energy Recovery from the Turbocharger and Preliminary Vehicle Energy Balance}

Thanks to the above described design modifications, the new turbocharger, operating in the configuration shown in Figure 6, delivers an extra power at all engine regimes, except below about $2500 \mathrm{rpm}$ (Figure 7): notice that the reported values include the mechanical and electrical efficiency and therefore represent net power. For any mission type (in the present study, a local semi-urban city path curve has been used, but the procedure obviously can be adapted to any type of mission, as well as ETC, EUDC, WVU and NEDC $[20,21])$, the engine energy balance is computed by calculating the instantaneous 
power request at the wheels [22-24], adding the transmission losses and the compressor power and subtracting the turbine power, and taking into account the charging efficiency of the battery pack. The effect of the KERS has not been included in the simulations presented here, because the relevant specifications are not available at the time of this writing. The results of the simulations are shown in Figures 8 and 9. For almost the entire mission, the turbocharger unit is able to deliver net extra power. This power will be used to feed the vehicle auxiliaries (lights, air conditioning, GPS, control panel, console, etc.). Where the power count is negative (almost always in restarts and sometimes during braking), the compressor will draw the required power from the on-board battery pack.

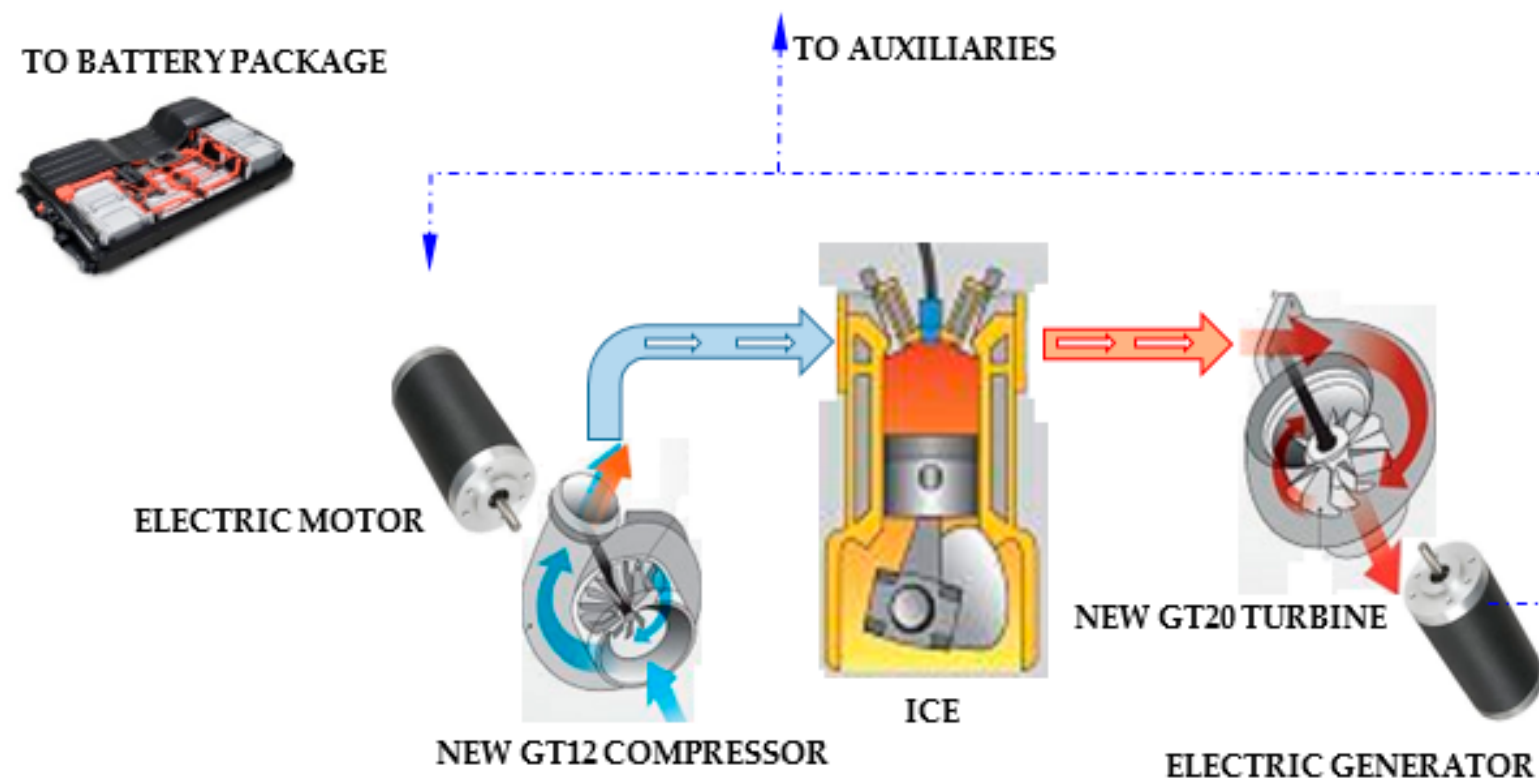

Figure 6. New operating engine configuration.

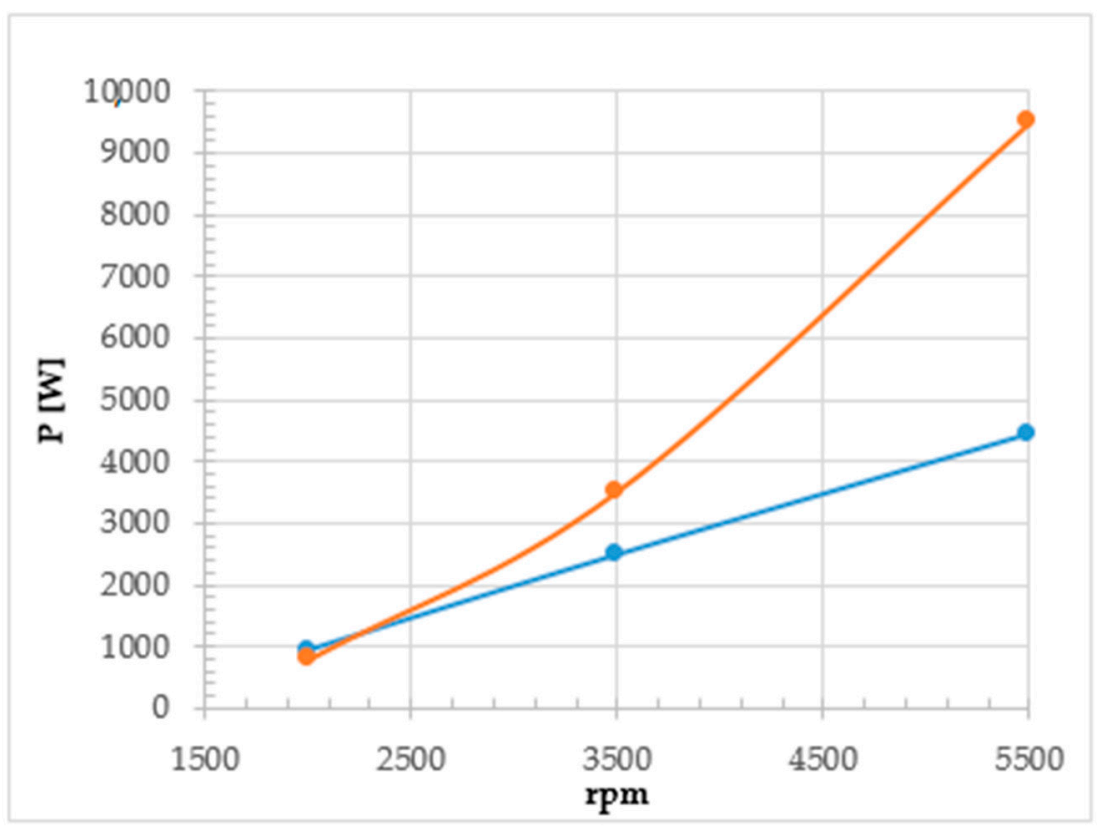

Figure 7. Turbine (orange) and Compressor (blue) power as a function of the ICE rpm. 


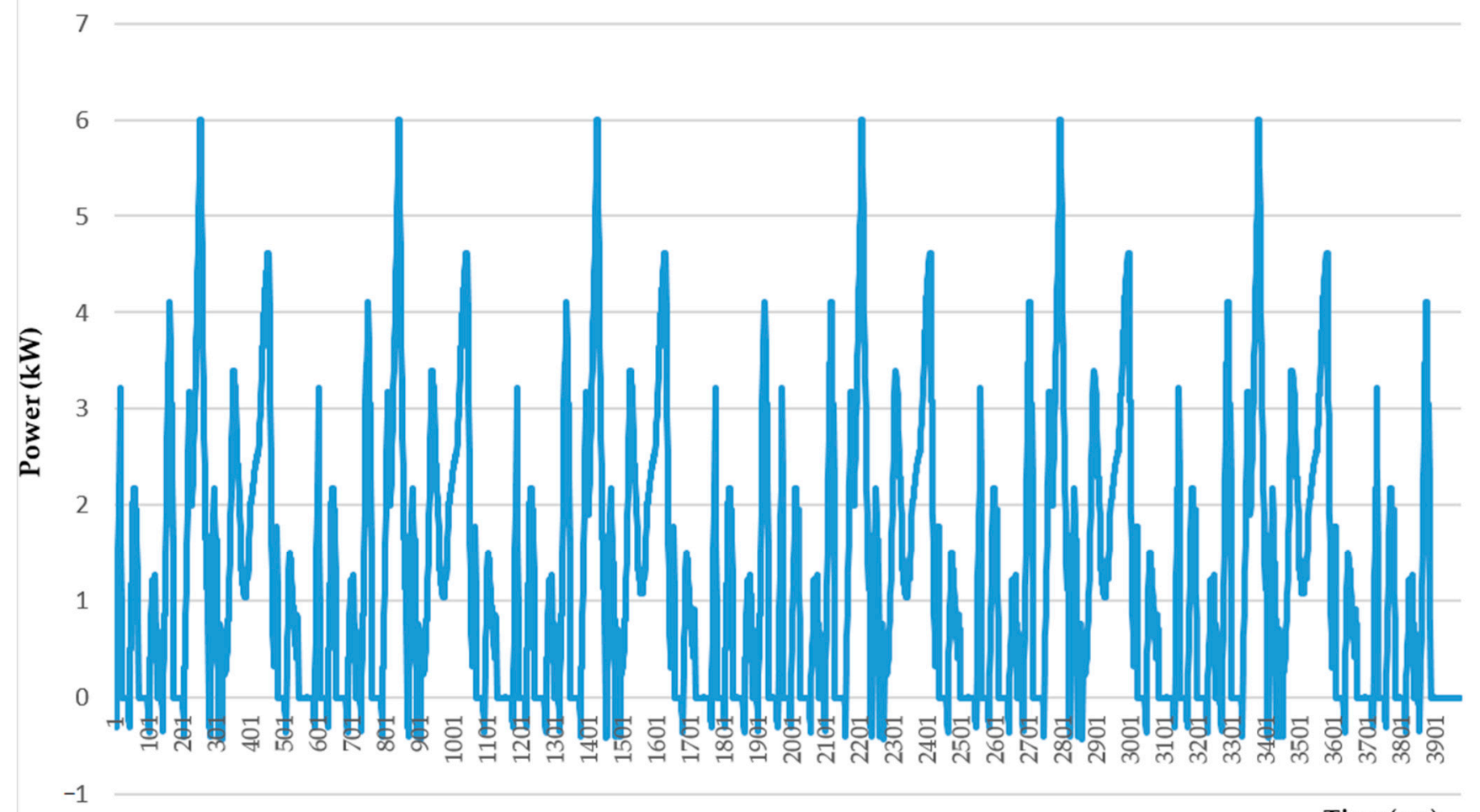

Figure 8. Net generated power $\left(\mathrm{P}_{\mathrm{TURB}}-\mathrm{P}_{\mathrm{COMP}}\right)$ during the mission.

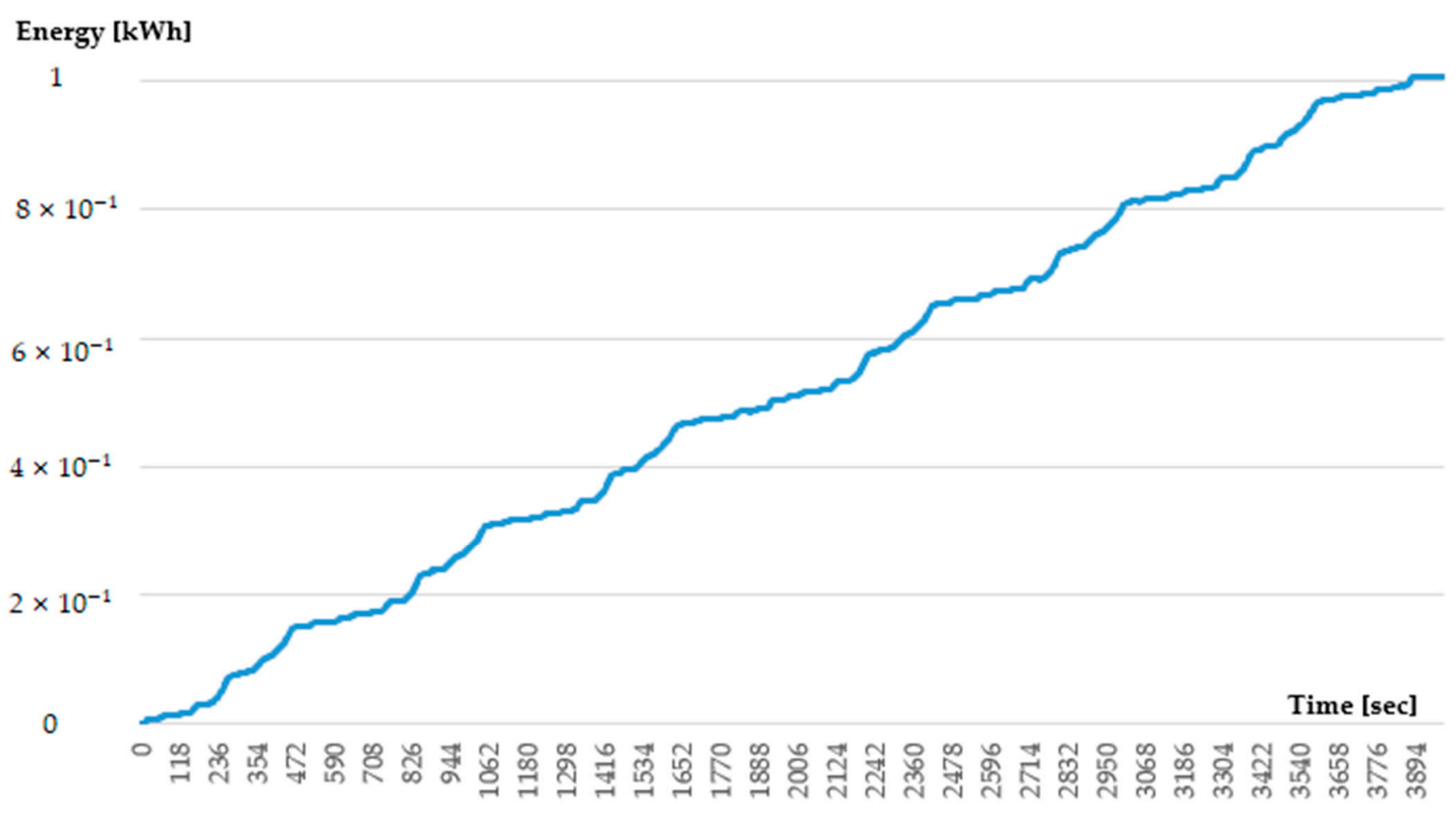

Figure 9. Net cumulative energy supplied by the turbocharger during the mission.

Since the vehicle is conceived as a mild hybrid, this battery pack is obviously much smaller than in an HEV or a BEV $[21,25]$. In longer missions, the instantaneous surplus 
generated by the turbocharger, discounted of the contributions dispatched to the auxiliaries, may lead to a condition in which the battery pack has a SOC (State of Charge) close to 100\% and cannot accept further charging. Under these circumstances, the extra power could be conveyed to an auxiliary electric motor for additional propulsion $[20,25,26]$. Such an option though will be considered only after the conclusion of the bench tests on the complete unit (ICE + turbocharger + battery pack).

\section{Discussion}

The general concept of obtaining extra "free" power by redesign of the turbocharger appears feasible. Major changes were introduced in the compressor, which is now in a tandem configuration (the stage is composed of an axial inducer and of a radial exducer, both mounted on the same shaft) and whose design has been independently optimized. The tandem unit has the same radial dimensions as the original GT12 but has a somewhat longer axial span because of the presence of the inducer: thus, a repackaging of the compressor assembly is necessary.

The electrical motor $[19,20]$ is mounted on the back of the rotor, so that the stage inlet is unobstructed. As for the turbine, although the redesign was relatively minor (blade number and curvature were changed, and a moving NGV added), the need for power required the installation of a larger unit, namely a modified version of the Garrett GT20: again, this requires a complete repackaging of the assembly, which would have been necessary anyhow, given the elimination of the waste-gate valve and the positioning of the electrical generator on the "colder" downstream side, properly shielded from the turbine discharge pipe.

Aside from the obvious advantage of generating excess power, the new turbocharger also performs better than the original one: it has a higher efficiency and is less sensitive to surge (in the compressor) and choking (in the turbine). Its only drawback is the fact that below $2500 \mathrm{rpm}$ (of the ICE) it absorbs power from the battery, although this does not seem to be a problem, at least in the simulated mission.

\section{Conclusions}

Within the frame of a broader research project, the present study deals with the redesign of the existing turbocharger unit in a 998 gasoline fueled city car. The proposed solution is to physically decouple compressor and turbine, powering the former by an electric motor and collecting the power of the latter by an electric generator. Both machines were redesigned, the compressor to a larger amount, to improve surge and choke characteristics. In the turbine (a modified Garrett GT20), variable-angle NGV were installed.

Complete simulations of both machines, presented elsewhere, demonstrated improved efficiencies as well, and provided operational curves that were used in the present study. A quite taxing mission profile was simulated, and the excess power calculated: the total energy recovered over the entire mission amounts to $1.01 \mathrm{kWh}$ (versus the $18 \mathrm{kWh}$ of total energy required by the vehicle), meaning that a net saving of about $5.6 \%$ can be attained by the installation of the novel turbocharger unit.

A series of bench tests to calibrate the electronic control units is also in the making, and their results will be the object of a separate paper.

Author Contributions: Conceptualization, R.C. and E.S.; methodology, R.C.; software, R.C. and E.S.; validation, E.S.; formal analysis, R.C.; investigation, R.C. and E.S.; resources, R.C.; data curation, R.C.; writing-original draft, R.C.; writing—review and editing, E.S.; visualization, R.C.; supervision, E.S.; project administration, R.C. All authors have read and agreed to the published version of the manuscript.

Funding: The study presented in this paper has been conducted within the frame of a broader project funded by the Italian Ministry of Research, project PRIN 2017—sector PE8-2017X8RFLE.

Institutional Review Board Statement: Not applicable.

Informed Consent Statement: Not applicable. 
Data Availability Statement: https://www.mdpi.com/ethics.

Conflicts of Interest: The authors declare no conflict of interest.

\begin{tabular}{|c|c|c|c|}
\hline \multicolumn{4}{|l|}{ Nomenclature } \\
\hline Symbol, Units & Description & Symbol, Units & Description \\
\hline BEV & Battery Electric Vehicle & MHV & Mild Hybrid Vehicle \\
\hline c [kJ/kg K] & Specific Heat & NEDC & New European Driving Cycle \\
\hline CAD & Computer Aided Design & NGV & Nozzle Guide Vanes \\
\hline CFD & $\begin{array}{l}\text { Computational Fluid } \\
\text { Dynamics }\end{array}$ & $\mathrm{P}[\mathrm{kW}]$ & Power \\
\hline EV & Electric Vehicle & $\mathrm{T}[\mathrm{K}]$ & Temperature \\
\hline EUDC & Extra Urban Driving Cycle & $\mathrm{W}[\mathrm{kJ}]$ or $[\mathrm{kWh}]$ & Work \\
\hline ETC & Emission Test Cycle & WVU & West Virginia University Cycle \\
\hline FCEV & Fuel Cell Electric Vehicle & Greek symbol & \\
\hline $\mathrm{HEV}$ & Hybrid Electric Vehicle & $\beta$ & Pressure ratio \\
\hline ICE & Internal Combustion Engine & $\kappa$ & Specific Heat Ratio \\
\hline KERS & $\begin{array}{l}\text { Kinetic Energy Recovery } \\
\text { System }\end{array}$ & $\varphi$ & Flow coefficient \\
\hline LPG & Liquified Petroleum Gas & $\psi$ & Load coefficient \\
\hline$\dot{m}[\mathrm{~kg} / \mathrm{s}]$ & Mass flowrate & $\eta$ & Efficiency \\
\hline
\end{tabular}

\section{References}

1. Singh, K.V.; Bansal, H.O.; Singh, D. A comprehensive review on hybrid electric vehicles: Architectures and components. J. Mod. Transp. 2019, 27, 77-107. [CrossRef]

2. Mi, C.; Masrur, A. Hybrid Electric Vehicles: Principles and Applications with Practical Perspectives; Wiley: Hoboken, NJ, USA, 2018.

3. Denton, T. Electric and Hybrid Vehicles; Routledge: London, UK, 2016.

4. Available online: https://www.garrettmotion.com/electric-hybrid/garrett-e-turbo/ (accessed on 1 September 2020).

5. $\quad$ BaljeO. Turbomachines, J; Wiley \& Sons: Hoboken, NJ, USA, 1981.

6. Shepherd, D.G. Principles of Turbomachinery, J; Macmillan Pub. Co.: Now York, NY, USA, 1956.

7. ATIP (Asian Technology Information Program) Scoop, Japan Office. Micro Gas Turbine Development; Tokyo, Japan, 2005. Available online: https://www.atip.org/index.php/atip-publications-2/atip-scoops/2005-2?start=40 (accessed on 28 December 2020).

8. Peirs, J.; Reynaerts, D.; Verplaetsen, F.; Norman, F.; Lefever, S. Development of a Micro Gas Turbine for Electric Power Generation. In Proceedings of the BE Paper Eurosensors XVII-The 17th European Conference on Solid-State Transducers, University of Minho, Guimaraes, Portugal, 21-24 September 2003.

9. Arav, B.L.; Shulman, R.; Kozminykh, V.A. Refinement of hybrid motortransmission set using micro turbine generator. In Proceedings of the International Conference on Industrial Engineering, Seville, Spain, 21-23 October 2015; Elsevier: Amsterdam, The Netherlands, 2015.

10. Ishihama, M.; Sakai, I.; Matsuzuki, K.; Hikone, T. Structural Analysis of Rotating Parts of an Ultra Micro Gas Turbine. In Proceedings of the International Gas Turbine Congress 2003, Tokyo, Janpan, 2-7 November 2003.

11. Gaydamaka, I.V.; Efimov, A.V.; Ivanov, M.J.; Ivanov, O.I.; Nigmatullin, R.Z.; Ogarko, N.I. Some Aerodynamic Performances of Small Size Compressor and Turbine Stages. In Proceedings of the International Gas Turbine Congress 2003, Tokyo, Janpan, 2-7 November 2003.

12. Van den Braembussche, R.A. Web Paper: Thermo-Fluid-Dynamic Design of Ultra Micro Gas-Turbine Components. Available online: https:/ / www.vki.ac.be/download/people/publications/publi_vandenbraembussche.pdf (accessed on 1 December 2019).

13. Cuturi, N.; Sciubba, E. Improvements in the design of a tandem compressor for an innovative turbocharger configuration for a hybrid city car. Int. J. Turbomach. Propuls. Power 2020, in press.

14. Matsuura, K.; Kato, C.; Yoshiki, H.; Matsuo, E.; Ikeda, H.; Nishimura, K.; Sapkota, R. Prototyping of Small-Sized Two Dimensional Radial Turbines. In Proceedings of the International Gas Turbine Congress 2003, Tokyo, Janpan, 2-7 November 2003.

15. Capata, R. Ultra Micro Gas Turbines. In Konstantin Volkov. Efficiency, Performance and Robustness of Gas Turbines; IntechOpen Limited 5 Princes Gate Court: London, UK, 2012; pp. 1-50.

16. Frechette, L.G.; Jacobson, S.A.; Breuer, S.K.; Ehrich, F.F.; Ghodssi, R.; Khanna, R.; Wong, C.W.; Zhang, X.; Schimdt, M.A.; Epstein, A.H. Demonstration of a micro-fabricated high-speed turbine supported on gas bearings. In Proceedings of the BE Paper Eurosensors XVII-The 17th European Conference on Solid-State Transducers, University of Minho, Guimaraes, Portugal, 21-24 September 2003.

17. Iwai, M. Thermodynamic Table for Performance Calculations. In Proceedings of the International Gas Turbine Congress 2003, Tokyo, Janpan, 2-7 November 2003.

18. Capata, R. Experimental tests of the operating conditions of a micro gas turbine device. J. Energy Power Eng. 2015, 9, 326-335. 
19. Silvestri, T. CFD Analysis of a Radial Turbine Stage with Variable NGV Control. Master's Thesis, Department of Mechanical and Aerospace Engineering, University of Roma Sapienza, Roma, Italy, 2020.

20. Wang, W.; Fu, R.; Fan, Y. Electromagnetic Parameters Matching of Permanent Magnet Synchronous Motor for Hybrid Electric Vehicles. Int. Fed. Autom. Control (IFAC) 2018, 51, 407-414. [CrossRef]

21. Stancu, C.; Ward, T.; Rahman, K.M. Separately Excited Synchronous Motor with Rotary Transformer for Hybrid Vehicle Application. IEEE Trans. Ind. Appl. 2017, 99, 1.

22. Ahmed, A.; Soffker, D. Towards Optimal Power Management of Hybrid Electric Vehicles in Real-Time: A Review on Methods, Challenges, and State-Of-The- Art Solutions. Energies 2018, 11, 476. [CrossRef]

23. Capata, R.; Sciubba, E. The low emission Turbogas hybrid vehicle concept-preliminary simulation and vehicle packaging. J. Energy Resour. Technol. 2013, 135, 13. [CrossRef]

24. Capata, R.; Sciubba, E. The Lethe (Low Emissions Turbo-Hybrid Engine) city car of the University of Roma 1: Final proposed configuration. Energy 2013, 58, 178-184. [CrossRef]

25. Capata, R. Urban and extra-urban hybrid vehicles: A technological review. Energies 2018, 11, 2924. [CrossRef]

26. Wei, Z.; Xu, J.; Halim, D. HEV power management control strategy for urban driving. Appl. Energy 2017, 194, 705-714. [CrossRef] 